\title{
High Temperature Evaluation of an Active Clearance Control System Concept
}

Shawn C. Taylor

University of Toledo, Toledo, Ohio

Bruce M. Steinetz

Glenn Research Center, Cleveland, Ohio

Jay J. Oswald

J\&J Technical Solutions, Cleveland, Ohio 


\section{NASA STI Program . . . in Profile}

Since its founding, NASA has been dedicated to the advancement of aeronautics and space science. The NASA Scientific and Technical Information (STI) program plays a key part in helping NASA maintain this important role.

The NASA STI Program operates under the auspices of the Agency Chief Information Officer. It collects, organizes, provides for archiving, and disseminates NASA's STI. The NASA STI program provides access to the NASA Aeronautics and Space Database and its public interface, the NASA Technical Reports Server, thus providing one of the largest collections of aeronautical and space science STI in the world. Results are published in both non-NASA channels and by NASA in the NASA STI Report Series, which includes the following report types:

- TECHNICAL PUBLICATION. Reports of completed research or a major significant phase of research that present the results of NASA programs and include extensive data or theoretical analysis. Includes compilations of significant scientific and technical data and information deemed to be of continuing reference value. NASA counterpart of peer-reviewed formal professional papers but has less stringent limitations on manuscript length and extent of graphic presentations.

- TECHNICAL MEMORANDUM. Scientific and technical findings that are preliminary or of specialized interest, e.g., quick release reports, working papers, and bibliographies that contain minimal annotation. Does not contain extensive analysis.

- CONTRACTOR REPORT. Scientific and technical findings by NASA-sponsored contractors and grantees.
- CONFERENCE PUBLICATION. Collected papers from scientific and technical conferences, symposia, seminars, or other meetings sponsored or cosponsored by NASA.

- SPECIAL PUBLICATION. Scientific, technical, or historical information from NASA programs, projects, and missions, often concerned with subjects having substantial public interest.

- TECHNICAL TRANSLATION. Englishlanguage translations of foreign scientific and technical material pertinent to NASA's mission.

Specialized services also include creating custom thesauri, building customized databases, organizing and publishing research results.

For more information about the NASA STI program, see the following:

- Access the NASA STI program home page at http://www.sti.nasa.gov

- E-mail your question via the Internet to help@sti.nasa.gov

- Fax your question to the NASA STI Help Desk at 301-621-0134

- Telephone the NASA STI Help Desk at 301-621-0390

- Write to:

NASA STI Help Desk

NASA Center for AeroSpace Information 7121 Standard Drive Hanover, MD 21076-1320 


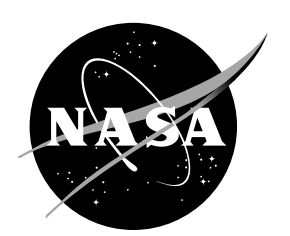

\section{High Temperature Evaluation of an Active Clearance Control System Concept}

Shawn C. Taylor

University of Toledo, Toledo, Ohio

Bruce M. Steinetz

Glenn Research Center, Cleveland, Ohio

Jay J. Oswald

J\&J Technical Solutions, Cleveland, Ohio

Prepared for the 42nd Joint Propulsion Conference and Exhibit cosponsored by AIAA, ASME, SAE, and ASEE

Sacramento, California, July 9-12, 2006

National Aeronautics and

Space Administration

Glenn Research Center

Cleveland, Ohio 44135 


\section{Acknowledgments}

The authors acknowledge Richard Tashjian (QSS Group, Inc.) for his excellent technical support in assembling the ACC hardware for testing.

Trade names and trademarks are used in this report for identification only. Their usage does not constitute an official endorsement, either expressed or implied, by the National Aeronautics and Space Administration.

Level of Review: This material has been technically reviewed by technical management.

Available from

NASA Center for Aerospace Information 7121 Standard Drive

Hanover, MD 21076-1320
National Technical Information Service 5285 Port Royal Road Springfield, VA 22161 


\title{
High Temperature Evaluation of an Active Clearance Control System Concept
}

\author{
Shawn C. Taylor \\ University of Toledo \\ Toledo, Ohio 43606 \\ Bruce M. Steinetz \\ National Aeronautics and Space Administration \\ Glenn Research Center \\ Cleveland, Ohio 44135 \\ Jay J. Oswald \\ J\&J Technical Solutions \\ Cleveland, Ohio 44130
}

\begin{abstract}
A mechanically actuated blade tip clearance control concept was evaluated in a nonrotating test rig to quantify secondary seal leakage at elevated temperatures. These tests were conducted to further investigate the feasibility of actively controlling the clearance between the rotor blade tips and the surrounding shroud seal in the high pressure turbine (HPT) section of a turbine engine. The test environment simulates the state of the back side of the HPT shroud seal with pressure differentials as high as 120 psig and temperatures up to $1000^{\circ} \mathrm{F}$. As expected, static secondary seal leakage decreased with increasing temperature. At $1000^{\circ} \mathrm{F}$, the test rig's calculated effective clearance (at 120 psig test pressure) was 0.0003 in., well within the industry specified effective clearance goal.
\end{abstract}

\section{Nomenclature}

$\phi \quad$ Flow factor, $\frac{\left(l b_{m} / s e c\right) \sqrt{{ }^{\circ} R}}{p s i a}$

$\mathrm{X}$ distance between the inner diameter of the face seal and inner edge of the flexure seal, in.

$\delta_{\text {flow }}$ effective clearance where flow is choked, in.

$A_{\text {flow }}$ Area where flow is choked, in. ${ }^{2}$

$C \quad$ Circumference of seal test section, in.

$\dot{m} \quad$ measured mass flow rate, $\mathrm{lb}_{m} / \mathrm{s}$

$R \quad$ gas constant for air, $53.3 \mathrm{lb}_{f}-\mathrm{ft} / \mathrm{lb}_{m^{-}}{ }^{\circ} \mathrm{R}$

$T$ temperature, ${ }^{\circ} \mathrm{R}$

$g_{c} \quad$ gravitational constant, $32.2 \mathrm{lb}_{m}-\mathrm{ft} / \mathrm{lb}_{f}-\mathrm{s}^{2}$

$P_{s} \quad$ supply pressure, psia

\section{Introduction}

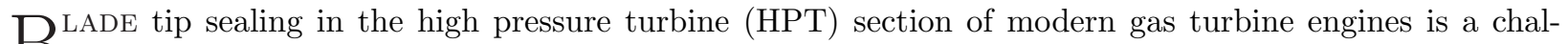
Blenging problem that holds great potential for making significant improvements to engine performance and efficiency. Reducing the clearance between the blade tips and sealing shrouds can reduce specific fuel consumption (SFC), lower emissions, increase the compressor stall margin, and extend payload and mission range capability. Current systems used to regulate blade tip clearance rely on scheduled cooling of the outer case flanges to reduce clearance during cruise conditions. These systems are relatively slow and do not monitor tip clearance for optimization. An improved system was designed and fabricated based on a fast-acting, active clearance control (ACC) concept. ${ }^{1}$ The ACC concept system uses real-time clearance measurement 
coupled with a fast-acting mechanical actuation system to accurately adjust blade tip clearance. This study builds on work performed by Steinetz, et al. ${ }^{2,3}$ that characterized the controllability and performance of the active clearance control concept at ambient temperature, and investigates its capabilities at elevated temperatures.

\section{A. Background}

Figure 1 is a cross section of the combustor and two-stage HPT of a modern gas turbine engine which shows the location of the HPT blade tip seal. ${ }^{1}$ Blade tip seals line the inside of the stationary case forming a shroud around the rotating blades that limits the amount of gas spilling over the tips. Blade tip clearance varies both over the operating stages (e.g., ground idle, takeoff, cruise, decel, etc.) and life of the engine. These clearance variations are produced by loads on both static and rotating parts, as well as component wear. An active clearance control concept was designed by Lattime, et al. ${ }^{1}$ to accommodate all of these sources of clearance fluctuation, including worst case clearance transients, such as those occurring in a "stopcock" event where the engine would be shut down in flight, allowed to windmill, and then be restarted to full power. This concept was incorporated into a test rig (Fig. 2) which was evaluated at ambient temperature on the basis of actuator controllability and secondary seal performance by Steinetz, et al. ${ }^{2,3}$ A more detailed overview of the ACC test rig is presented in the "Test Apparatus" section. By actively controlling HPT blade tip clearance, noted clearance fluctuations can be mitigated, and optimized, constant clearance levels can be established.

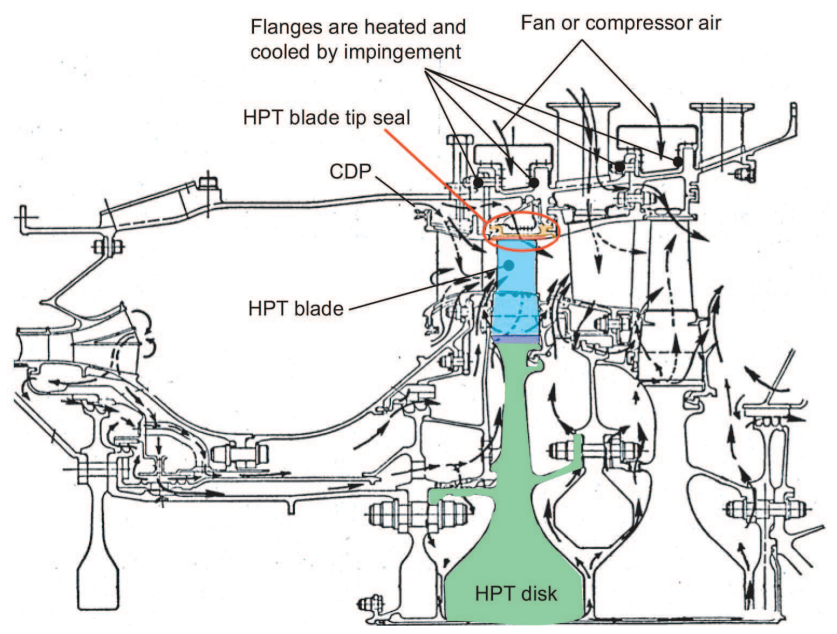

Figure 1. HPT blade tip seal location in a modern gas turbine engine. ${ }^{4}$

Tighter tip clearance reduces the amount of air that spills over the blade tips and increases turbine efficiency. This allows the engine to meet thrust and performance requirements while operating at lower temperatures, with less fuel burn, and lower rotor inlet temperatures. Decreased turbine operating temperature increases the service life of internal hot section components and extends the useful life of the engine between overhauls. A reduction in blade tip clearance of 0.010 in. would decrease exhaust gas temperature (EGT) by approximately $10^{\circ} \mathrm{C} .{ }^{5}$ Deterioration of the EGT margin is the primary parameter used to determine when an engine is removed from service. The noted $0.010 \mathrm{in}$. clearance decrease would also reduce specific fuel consumption by 0.8 to $1 \%$, and lower $\mathrm{NO}_{x}, \mathrm{CO}$, and $\mathrm{CO}_{2}$ emissions. Other benefits include enhanced payload and mission range capabilities. Additional discussion of the possible benefits of advanced active clearance control systems are presented by Lattime, et al., ${ }^{5} \mathrm{GE},{ }^{6}$ and Wiseman and Guo. ${ }^{7}$ 


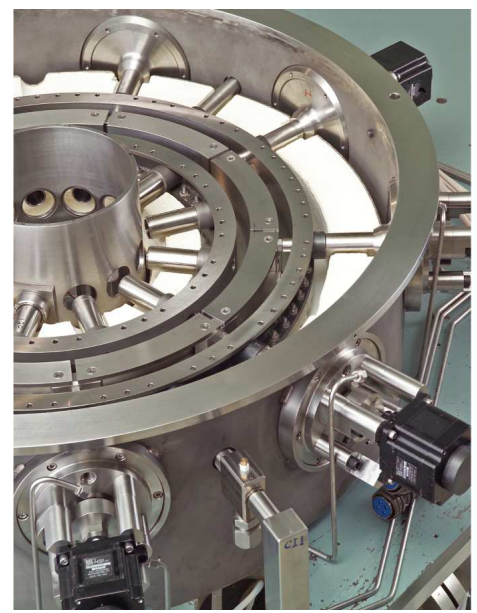

(a) Overall view

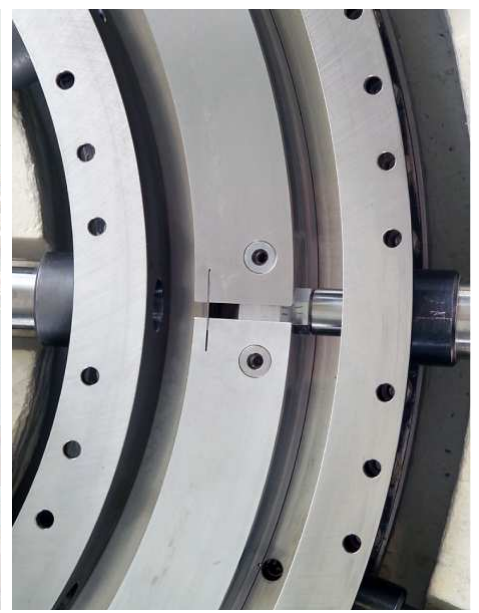

(b) Close up

Figure 2. Photographs of the active clearance control test rig: (a) Overall test rig; (b) Close up of two linked seal carrier segments.

\section{B. Objectives}

This work is part of a larger research effort to develop improved approaches for clearance control systems for use in the HPT section of large commercial aircraft engines. The current investigation augments previous studies that evaluated the performance of the ACC test rig at room temperature by characterizing the performance of the rig at elevated test temperatures. Primary focus was placed on determining the effect that elevated test temperature has on the secondary seal leakage of the ACC system. Specific goals of this study included:

- Quantify improvements made to ACC seal components at room temperature and establish a baseline system leakage to compare with elevated temperature leakage rates.

- Determine the effect of test temperature on static leakage at a given seal carrier position.

- Determine whether the observed dependence of room temperature leakage on seal carrier position is still present at higher test temperatures.

- Determine if direction of seal carrier motion (radially inward or outward) impacts high temperature seal leakage.

\section{Test Facility and Procedures}

\section{A. Test Apparatus}

\section{General Overview}

The ACC test rig (Fig. 3) was designed to simulate the temperature and pressure conditions of the environment surrounding the backsides of the turbine shroud segments. This rig is used to evaluate actuation systems in a "static" environment without blade rotation. Rig specifications were selected based on current engine requirements. Table 1 compares the main characteristics of the ACC test rig to a typical modern high bypass ratio engine.

The Inconel 718 (Special Metals Corp., Huntington, WV) seal carrier assembly shown in Figs. 3 and 4 is a concept that would be used in a turbine to support the tip seals that surround the rotor. The assembly consists of nine individual segments that are connected through a series of Inconel 718 "links" (Fig. 4) to form a circular shroud. One connection between the link and carrier is a pinned joint, and the other is a slotted joint. Each link (9 total) is rigidly connected to an Inconel 718 actuator rod which is attached to a stepper motor that provides the radial motion needed to control simulated blade tip clearance. This 
Table 1. Comparison of ACC rig design to the operating characteristics of a typical modern high bypass ratio engine. ${ }^{2}$

\begin{tabular}{|l|c|c|}
\hline Parameter & ACC Rig Design & Reference Engine \\
\hline Shroud backside pressure (psia) & 150 & 500 \\
Pressure differential (psid) & 120 & 150 \\
Shroud backside temperature & & \\
$\quad$ Current $\left({ }^{\circ} \mathrm{F}\right)$ & 1000 & 1250 \\
$\quad$ Future $\left({ }^{\circ} \mathrm{F}\right)$ & 1250 to 1300 & 1250 to 1300 \\
Diameter (in.) & 20 & 30 \\
Shroud face width (in.) & 2 & 2 \\
Number of shrouds/seal carriers & 9 & 16 \\
Pressure induced load on actuator $\left(\mathrm{lb}_{f}\right)$ & 1650 & 1750 \\
Nominal clearance change (i.e., stroke) (in.) & 0.190 & 0.050 \\
Clearance change rate (in./sec) & 0.01 & 0.01 \\
Clearance measuring techniques & & not used \\
$\quad$ Current & capacitance & capacitance/microwave \\
$\quad$ Future (under development)
\end{tabular}

kinematic arrangement allows for dilation of the seal carrier shroud when the actuator rods are moved radially outward and contraction when they are moved inward. Dilation of the seal carrier shroud increases simulated tip clearance, and contraction decreases clearance. Stepper motor control is implemented through National Instruments controllers and a series of algorithms coded in LabVIEW (National Instruments Corp., Austin, TX). Details of ACC test rig control system are presented by Steinetz, et al. ${ }^{2}$

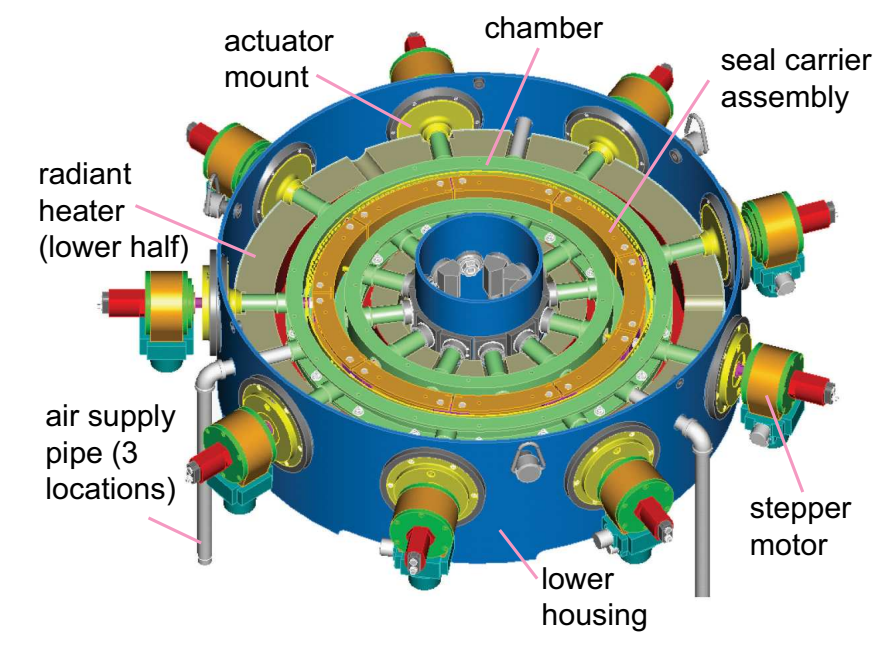

Figure 3. ACC test rig with housing lid and chamber cover plate removed. ${ }^{1}$

The seal carrier shroud is encased in a test chamber that is used to create the temperature (T3) and pressure (P3) conditions typical of the environment behind the blade tip seals in an actual HPT. The test chamber consists of an upper and lower cover plate, and inner and outer walls (Fig. 4). Hot, high pressure air is supplied to the backside of the seal carrier shroud through three penetrations $\phi$ f the outer chamber wall. The hot air (provided by a $35 \mathrm{~kW}$ inline air heater) heats the inside of the test chamber, and is the medium for evaluating seal leakage. The outside of the test chamber is heated by the upper and lower halves of a split annular radiant heater (Fig. 4). Combined, these two systems provide the heat needed to simulate the T3 environment. Additional detai[ $\emptyset$ f the ACC heater systems is provided by Lattime, et al. ${ }^{1}$ 


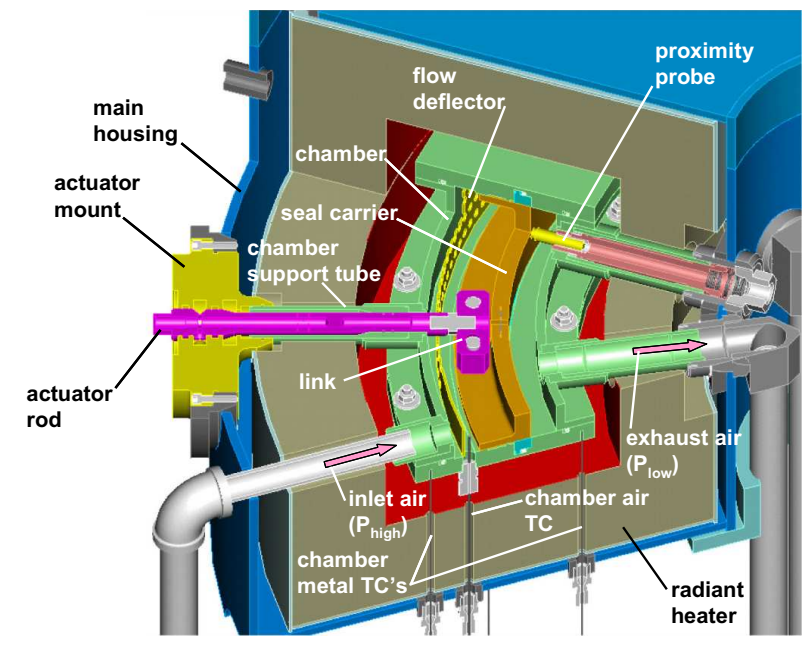

Figure 4. ACC cut-away showing internal rig components. ${ }^{1}$

\section{Secondary Seals}

To maintain a significant positive backpressure and create the desired P3 pressure differential across the seal carrier shroud, multiple secondary seals are required. These seals are highlighted in Fig. 5. The top and bottom of the seal carrier shroud are sealed with face seals (Stellite 6b (Deloro Stellite Co., Goshen, IN)) secured in grooves in the upper and lower chamber cover plates and preloaded by E-seals (Waspaloy (Haynes International, Inc., Kokomo, IN)). The flow path between the individual seal carriers is blocked by thin, pressure activated flexure (spline) seals (Inconel X-750 (Special Metals Corp., Huntington, WV)). The flexure seals are inserted into precision slots machined into the ends of the seal carriers. When the test chamber is pressurized, the faces of the flexure seals seat on the low pressure side of the mounting slot (radially inward side) and seal along their top and bottom edges with the face seals. Since the flexure edges must mate with the face seals to sustain a backpressure, the stroke length of the rig's actuation system is governed by the width of the face seal. The center of this stroke (flexure seals in the center of the face seal) is referenced as the nominal "home" position of the seal carrier shroud. Waspaloy C-seals are used to prevent leakage between the test chamber cover plates and the chamber wall flanges. Piston ring seals (Stellite 25 (Deloro Stellite Co., Goshen, IN) and Inconel 625 (Special Metals Corp., Huntington, WV)) are used to minimize flow past the actuator rod and air supply locations. Additional information on the design of the test chamber and seal components is given by Lattime, et al., ${ }^{1}$ and component leakage levels for each seal at room temperature are presented by Steinetz, et al. ${ }^{2}$ 


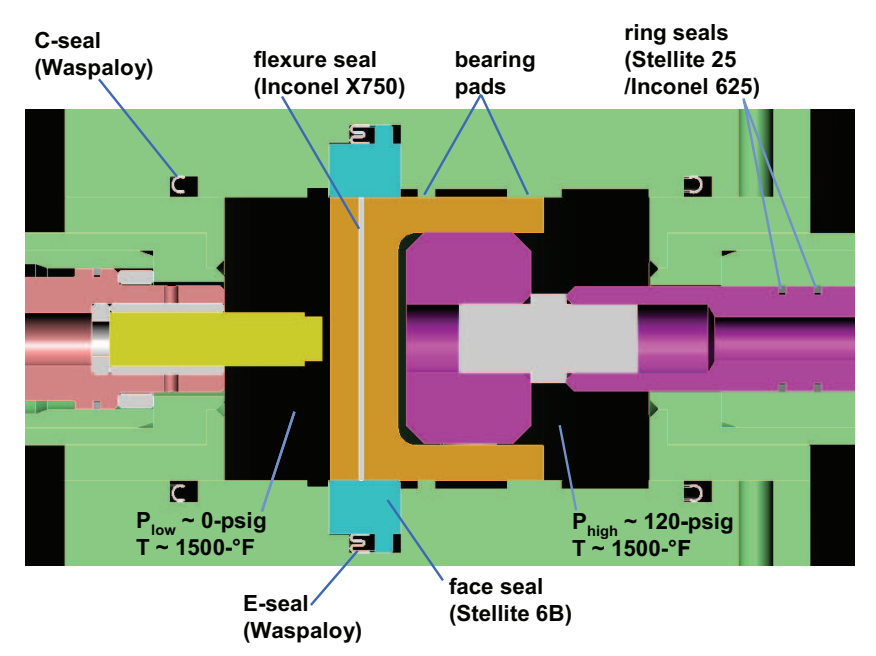

Figure 5. Chamber detail showing seal locations.

\section{Instrumentation}

Simulated clearance values are continuously monitored during testing with four capacitance based proximity probes. Three probes are positioned at $90^{\circ}$ intervals and the fourth probe is offset from the nearest adjacent probe by $30^{\circ}$. Probe details are listed in Table 2, Leakage values are collected using a mass flow meter. Specifications for the flow meter, pressure transducers, and thermocouples used to monitor the ACC test environment are provided in Table 3.

Table 2. Clearance probe specifications.

\begin{tabular}{|l|c|}
\hline Maximum compensated temperature $\left({ }^{\circ} \mathrm{F}\right)$ & 1500 \\
\hline Measurement range (in.) & 0 to 0.125 \\
\hline Accuracy (in.) & 0.0002 \\
\hline Resolution (in.) & 0.00005 \\
\hline Excitation voltage (V) & 15 \\
\hline Probe diameter (in.) & 0.375 \\
\hline Weight (lbs) & 0.04 \\
\hline
\end{tabular}

Table 3. Instrumentation specifications.

\begin{tabular}{|cc|}
\hline Thermocouples & Type K \\
\hline Accuracy $\left({ }^{\circ} \mathrm{F}\right)$ & \pm 4 \\
\hline Pressure Transducers & \\
\hline Accuracy $(\mathrm{psi})$ & 0.12 \\
Range $(\mathrm{psi})$ & 0 to 300 \\
\hline Flow Meter & \\
\hline Accuracy $\left(\mathrm{lb}_{m} / \mathrm{s}\right)$ & $0.0022(1.2 \% \mathrm{FS})$ \\
Range $\left(\mathrm{lb}_{m} / \mathrm{s} ; \mathrm{SLPM}\right)$ & $0.19 ; 4000$ \\
\hline
\end{tabular}




\section{B. Improving Baseline Seal Performance}

Previous investigation of secondary seal leakage in the ACC test rig found an overall system leak rate of $0.139 \mathrm{lb}_{m} / \mathrm{s}$ at room temperature when the seal carriers were centered at the home position and chamber pressure was 100 psig. $^{2}$ Since that study, significant work has been directed toward lowering system leakage. Better alignment of the actuators, rods, and their support tubes reduced off axis loading during actuation and enhanced sealing between the piston rings and the inside of the support tubes. Additional sealing improvement stemmed from wear-in of mating metal seal components (piston rings and tubes, face seals and seal carriers, flexure seals and seal carrier slots) that occurred during continued rig operation. Wear-in benefits were augmented by dressing the metal sealing surfaces to remove burrs and frictional abrasions incurred during testing, and coating them molybdenum disulfide solid film lubricant. This reduced seal carrier average surface roughness $\left(\mathrm{R}_{a}\right)$ from $20 \mu \mathrm{in}$. to $13 \mu \mathrm{in}$. Combined, these efforts to reduced the overall system leakage (room temperature at $100 \mathrm{psig}$ ) to approximately $0.105 \mathrm{lb}_{m} / \mathrm{s}$ (a $24 \%$ decrease from the original value).

\section{Elevated Temperature Evaluation - General Procedures and Background}

Building on procedures used for room temperature evaluations of the ACC test rig, ${ }^{2}$ additional seal leakage tests were conducted to characterize the performance of the system at elevated temperatures. Nominal test temperatures included $500^{\circ} \mathrm{F}, 800^{\circ} \mathrm{F}$ and $1000^{\circ} \mathrm{F}$. To achieve these temperatures, the test chamber was heated internally with hot air supplied by a single air heater and externally by the radiant heater (Fig. 4). The two independent heat sources were ramped at equivalent rates (nominally $50^{\circ} \mathrm{F} / \mathrm{min}$.) to prevent the formation of significant thermal gradients across the test chamber and promote a uniform expansion of internal rig components. Due to the large thermal mass of the Inconel rig internals, actual heating rates were somewhat slower. To compensate for the temperature lag, the rig was subjected to a heat soak interval until monitored internal component temperatures equalized at the uniform, steady state value prescribed for the test.

Prior to heatup, the nine seal carriers were centered about the rig's central axis in range of the capacitance probes so their positions could be tracked during both heatup and testing. Previous room temperature investigations found some dependence of seal leakage on the radial position of the seal carriers. Increased leakage values were observed when the carriers were positioned radially inward of the nominal home position, and decreased leakage levels were noted as the carriers were moved radially outward of the home position. ${ }^{2,3}$ Based on these observations, leakage values for similar face seal/seal carrier positions were needed to make meaningful comparisons of seal performance for varied conditions. Capacitance probe clearance values alone did not provide sufficient seal location information for leakage comparison because the clearance readings are affected by thermal expansion of internal rig components. Experimental clearance values were combined with calculated thermal expansions of relevant rig components (based on first principles) into a new positional parameter, termed X (Fig. 6). X was defined as the distance from the inner diameter of the face seal to the inner edge of the flexure seal when positioned in its slot in the seal carrier. $\mathrm{X}$ accommodated seal carrier motion resulting from mechanical actuation, pressure induced displacements, and thermal expansion, and allowed the relative orientation of the face seals, flexure seals, and seal carriers to be readily determined for a given test temperature. With this information, accurate leakage comparisons were made between varied test conditions (pressure, temperature, etc.). When the seal carriers were at the home position, $\mathrm{X}=0.250$ in.

\section{Test Specific Procedures}

\section{Static Leakage Dependence on Temperature and Pressure}

The effect of test temperature on static seal leakage was evaluated at $500^{\circ} \mathrm{F}, 800^{\circ} \mathrm{F}$ and $1000^{\circ} \mathrm{F}$. Prior to starting each test, the nine seal carriers were centered about the rig's central axis and positioned radially inward of the nominal home position $(\mathrm{X}<0.250$ in.) in range of the capacitance probes. The test chamber was gradually heated using both the air and radiant heaters as previously described. Seal carrier clearance was monitored during this process, and as thermal expansion of the actuator rods pushed the seal carriers radially inward, the stepper motors were incrementally adjusted to move the carriers outward and maintain their position in range of the capacitance probes. Once the test chamber reached the desired steady state test temperature, the seal carriers were positioned to place the flexure seals approximately $0.125 \mathrm{in}$. from 
the inner edge of the face seal $(\mathrm{X}=0.125 \mathrm{in}$.). This location was selected because the seal carriers were in range of the capacitance probes for all three test temperatures without modifying the configuration of the probes, whereas at the home position they were not. Both metal and air temperatures were collected during all tests, but the air temperature inside the chamber, behind the seal carriers was referenced as the nominal test temperature. Leakage values were collected at chamber pressures ranging from 60 psig to 120 psig in 20 psig increments.

\section{Static Leakage Dependence on Seal Carrier Position at Elevated Temperatures}

Tests were conducted at $500^{\circ} \mathrm{F}, 800^{\circ} \mathrm{F}$ and $1000^{\circ} \mathrm{F}$ to determine whether previously noted static leakage dependence on seal carrier position was still present at elevated test temperatures. At each temperature, the seal carriers were incrementally moved across the available stroke range. The outer stroke limit was dictated by the range of the capacitance probes, and the inner limit was defined to prevent a kinematic "archbind" of the seal carriers (the inner limit decreased with increasing temperature due to thermal expansion of rig components). The carriers were first positioned at the inner-most position (smallest $\mathrm{X}$ value), and then moved radially outward. Every 0.010 in. the seal carriers were stopped and static leakage data was collected for chamber pressures ranging from 60 psig to 120 psig, incremented in 20 psig intervals. Chamber pressure was decreased to 10 psig prior to moving the seal carriers to stay within the load limitations of the stepper motors. (Note: Limited force capacity stepper motors were used for these studies but are being replaced with full capacity hydraulic actuators for future evaluations.)

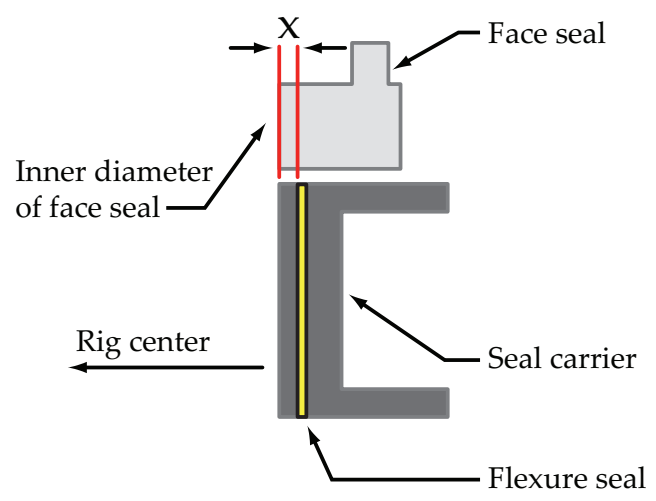

Figure 6. Graphical depiction of the X dimension.

\section{Effect of Seal Carrier Direction of Motion on Elevated Temperature Static Leakage}

Tests to determine the effect of seal carrier direction of motion on seal leakage at elevated temperatures were continuations of the tests used to investigate the influence of position on leakage. During these tests, when the seal carriers reached the outer-most position of the outward stroke, direction of motion was reversed, and they were actuated radially inward. Chamber pressure was again reduced to 10 psig prior to carrier movement to avoid stepper motor load limitations. Actuation was stopped every 0.010 in. during the inward stroke and leakage data was collected for test pressures ranging from 60 to 120 psig (increased in 20 psig increments). Test temperatures included $500^{\circ} \mathrm{F}, 800^{\circ} \mathrm{F}$, and $1000^{\circ} \mathrm{F}$.

\section{Results and Discussion}

\section{A. Static Leakage Dependence on Temperature and Pressure}

As expected, increasing test temperature significantly decreased seal leakage over the span of temperatures and pressures evaluated. Figure 7(a) presents a comparison of seal leakage vs. test temperature for a chamber pressure of 120 psig. When referenced to room temperature seal leakage at the same pressure, increasing the test temperature to $500^{\circ} \mathrm{F}$ decreased mass flow by $46 \%$. Further temperature increases to $800^{\circ} \mathrm{F}$ and $1000^{\circ} \mathrm{F}$ produced corresponding flow reductions of $62 \%$ and $64 \%$, respectively (compared to room temperature condition data). The dominant mechanism relating seal leakage and test temperature has not been identified. However, when the mass flow rate vs. temperature data is converted to a flow factor,

$$
\phi=\frac{\dot{m} \sqrt{T}}{P_{s}}
$$

a similar trend of temperature dependence is observed (Fig. 7(b)). At room temperature, the calculated flow factor is $0.018 \frac{(\mathrm{lbm} / \mathrm{sec}) \sqrt{{ }^{\circ} R}}{\mathrm{psia}}$. Increasing the test temperature to $500^{\circ} \mathrm{F}$ reduced the flow factor by $28 \%$. Further temperature increases showed that the flow factor decreased $39 \%$ from the room temperature value at $800^{\circ} \mathrm{F}$, but then leveled off at $1000^{\circ} \mathrm{F}$. Based on these observations, the temperature dependence 
shown in Fig. 7(a) in the 800 to $1000^{\circ} \mathrm{F}$ regime can be explained via normal gas density variation with temperature. At the lower temperatures, other factors such as temperature dependent clearances may be playing a role. Further investigation is required to identify which factors are the most prevalent in governing high temperature seal leakage.

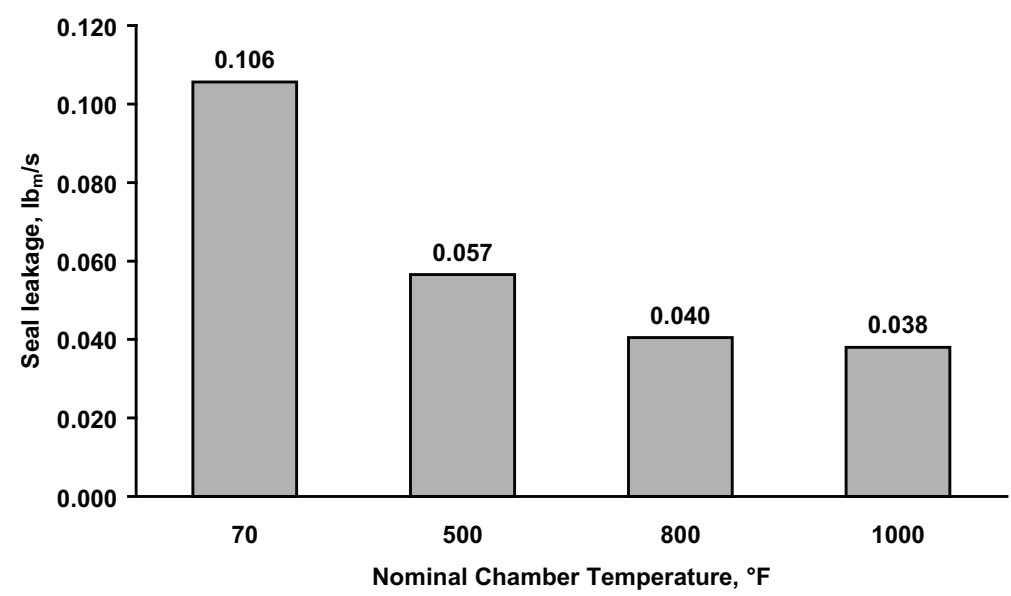

(a) mass flow

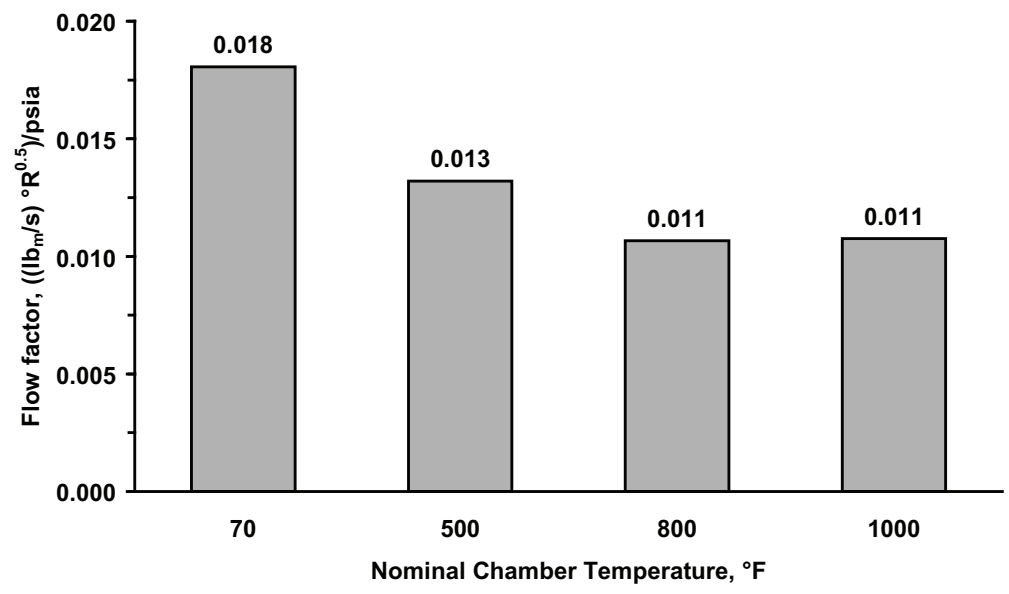

(b) flow factor

Figure 7. ACC seal leakage vs. chamber temperature at $120 \mathrm{psig}, \mathrm{X}=0.125 \mathrm{in}$. Seal leakage expressed as (a) mass flow and (b) flow factor.

Secondary seal leakage dependence on pressure (for all three elevated test temperatures) is highlighted in Fig. 8. As expected, increasing chamber pressure increased seal leakage, and for the test conditions evaluated herein, this increase appeared to follow a linear trend. This data was collected at a nominal X value of 0.125 in., which corresponds to the data presented in Fig. 7(a). 


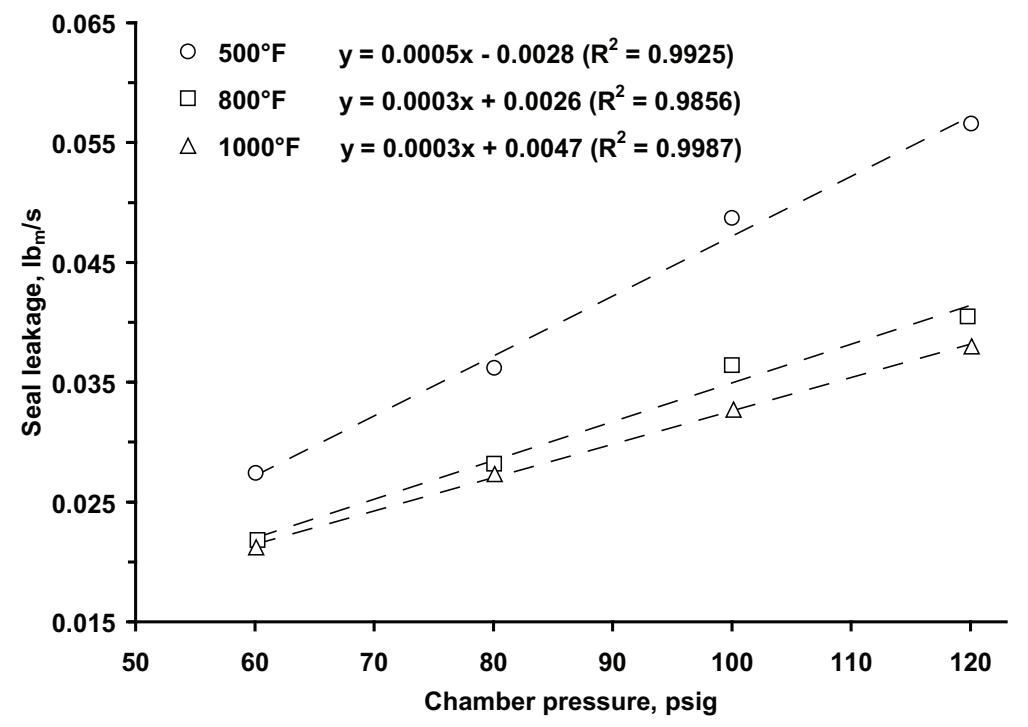

Figure 8. Seal leakage vs. chamber pressure at 500,800 , and $1000^{\circ} \mathrm{F}(\mathrm{X}=0.125$ in. $)$.

\section{B. Static Leakage Dependence on Seal Carrier Position at Elevated Temperatures}

Seal carrier position had some influence on seal leakage at both 500 and $800^{\circ} \mathrm{F}$. Figure 9 plots seal leakage vs. seal carrier position (in terms of X) for the 120 psig chamber pressure case. The highest leakage values at 500 and $800^{\circ} \mathrm{F}\left(0.063\right.$ and $0.050 \mathrm{lb}_{m} / \mathrm{s}$, respectively) were logged when the seal carriers were at their inner-most position (smallest X). As the carriers were moved radially outward, leakage levels decreased. Across the evaluated stroke range of approximately 0.055 in., seal leakage decreased by approximately $21 \%$ at $500^{\circ} \mathrm{F}$, and by $26 \%$ at $800^{\circ} \mathrm{F}$. This trend was not observed in the $1000^{\circ} \mathrm{F}$ leakage data. As shown in Fig. 9. leakage values at $1000^{\circ} \mathrm{F}$ for the tested stroke range never deviate from one another by more than 0.002 $\mathrm{lb}_{m} / \mathrm{s}$, which falls inside the accuracy limit of the mass flow meter used in the study. Similar behavior was also observed at the lower test pressures.

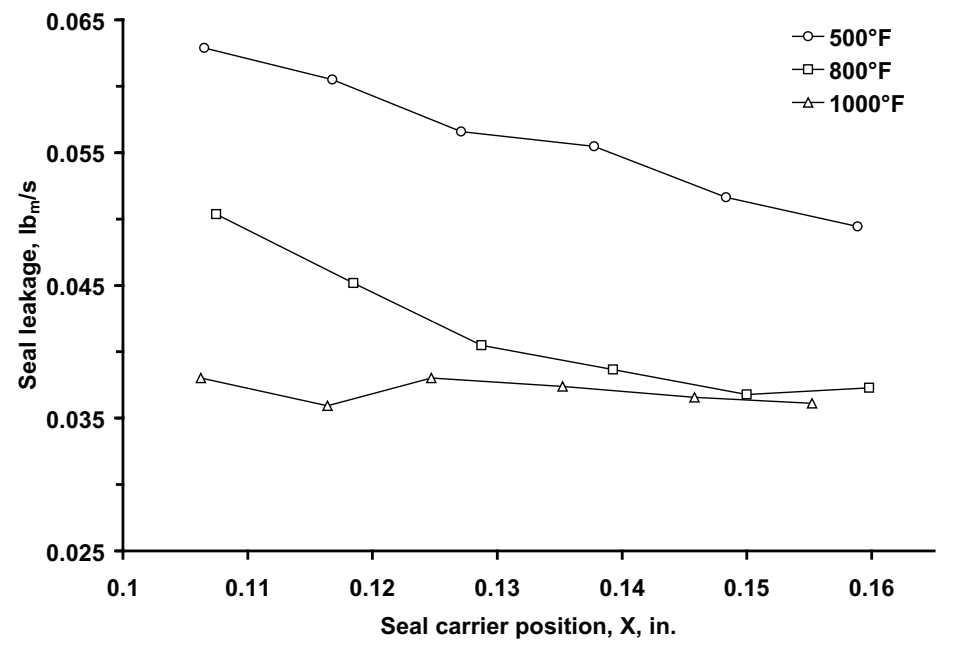

Figure 9. Seal leakage vs. seal carrier position (in terms of X) at 120 psig. 


\section{Effect of Seal Carrier Direction of Motion on Elevated Temperature Static Leakage}

Previous room temperature testing showed that static leakage is typically lower when recorded during an inward stroke of the seal carriers. ${ }^{2}$ This trend does not appear to be consistently present at all elevated test temperatures. At $500^{\circ} \mathrm{F}$ a slight dependence on direction of seal carrier motion was observed. As shown in Fig. 10, lower leakage values were observed for $\mathrm{X}$ values ranging from approximately $0.105 \mathrm{in}$. to $0.130 \mathrm{in}$. when collected during the inward seal carrier stroke. The largest leakage reduction, $0.015 \mathrm{lb} m / \mathrm{s}$, occurs at an $\mathrm{X}$ value of $0.118 \mathrm{in}$. Outside of that positional range, however, actuation direction does not appear to have an effect on seal leakage, considering the minor leakage variations and the measurement accuracy of the flowmeter (highlighted by the error bars). During the inward stroke at $500^{\circ} \mathrm{F}$, a weak leakage dependence on seal carrier position is still observed. At the innermost position, a leakage of $0.065 \mathrm{lb}_{m} / \mathrm{s}$ was recorded, and at the outermost position leakage was only $0.051 \mathrm{lb} m / \mathrm{s}$. Figure 11 plots the $800^{\circ} \mathrm{F}$ data and shows no relationship between seal carrier direction of travel and seal leakage for $\mathrm{X}$ values larger than approximately 0.125 in. At positions where $\mathrm{X}$ was smaller than 0.125 in., leakage values were slightly lower during the inward stroke, compared to leakages collected during the outward stroke across the same $\mathrm{X}$ range. At $1000^{\circ} \mathrm{F}$, there were no discernable trends to suggest that direction of seal carrier motion has any influence on system leakage (Fig. 12). Any observed flow variations at that temperature were well within the error range of the mass flow meter.

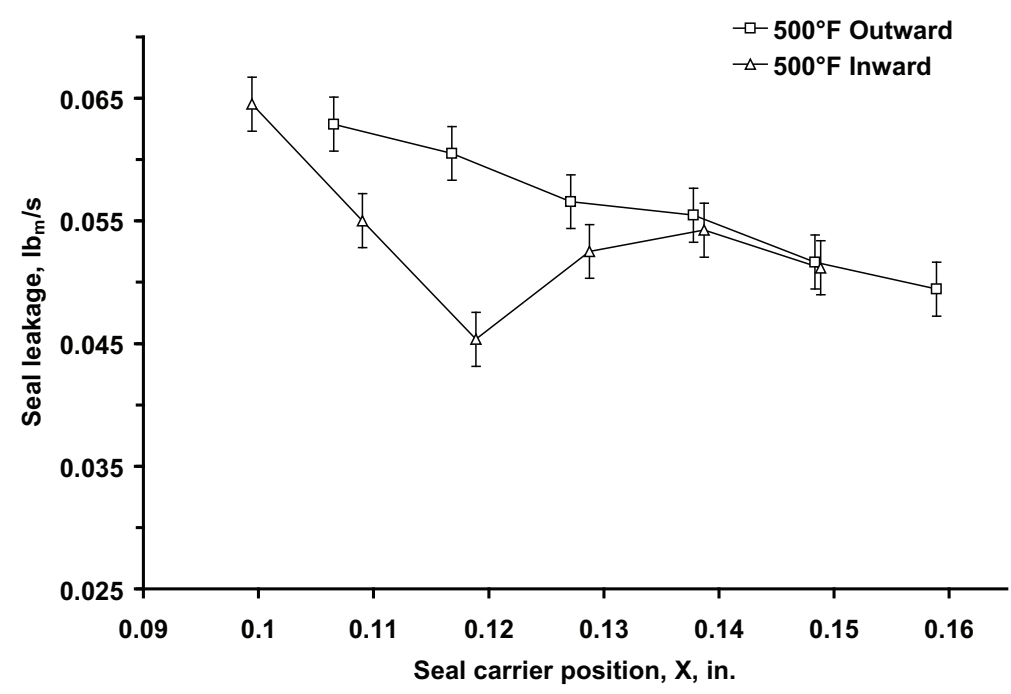

Figure 10. Static leakage dependence on direction of seal carrier motion at $500^{\circ} \mathrm{F}$. 


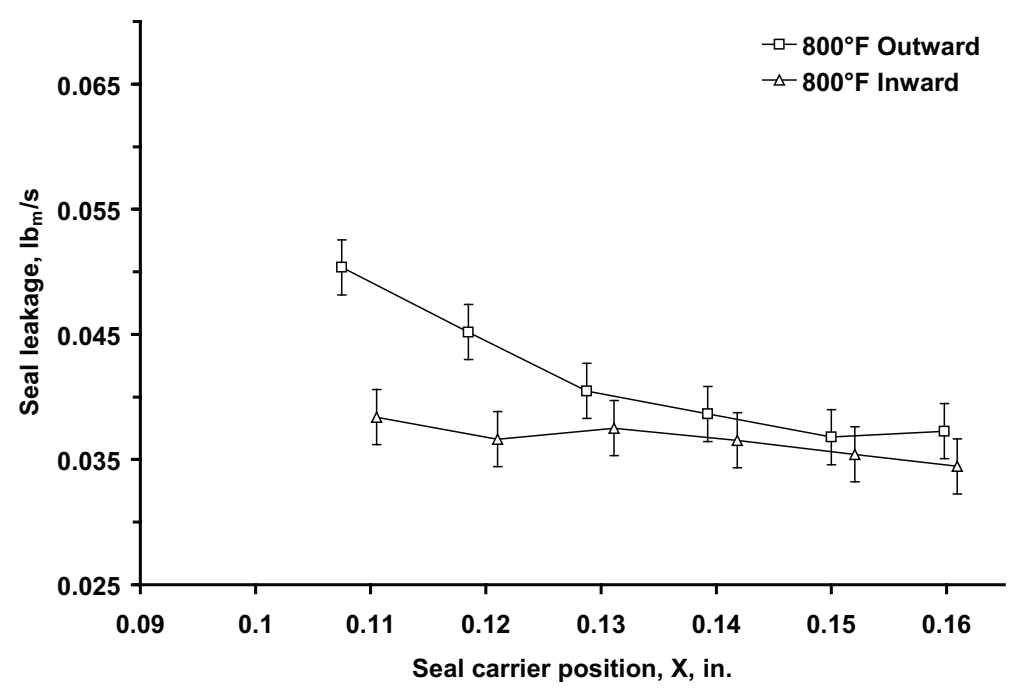

Figure 11. Static leakage dependence on direction of seal carrier motion at $800^{\circ} \mathrm{F}$.

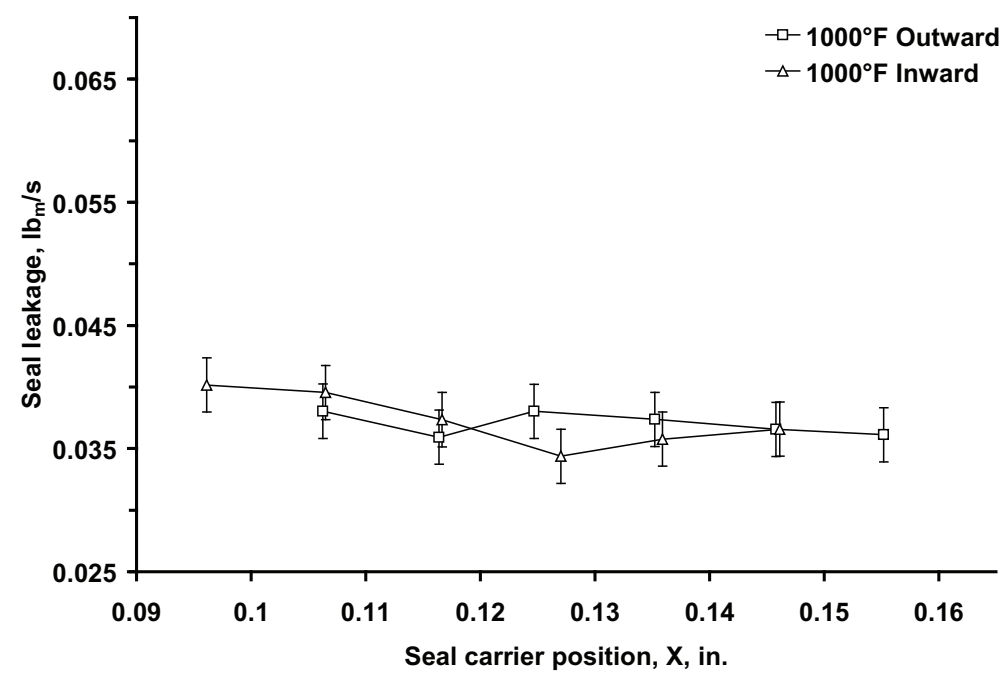

Figure 12. Static leakage dependence on direction of seal carrier motion at $1000^{\circ} \mathrm{F}$.

\section{Comparison of Effective Clearance to an Industry Reference Level}

Low secondary seal leakage in an ACC system is critical to harvesting the improved efficiency benefits obtainable through tighter blade tip clearance in the HPT. As such, a practical benchmark is required to track rig performance across different builds and varying test conditions. By assuming isentropic flow with compressibility at the choked flow condition, a method for back-calculating effective clearances for the ACC test rig at multiple test conditions was derived. ${ }^{2,8}$ The equation used for these calculations is:

$$
\delta_{\text {flow }}=\frac{A_{\text {flow }}}{C}=\frac{\dot{m} \sqrt{R T}}{0.6847 \sqrt{g_{c}} P_{s} C}
$$

To obtain the desired benchmark for comparison, an effective clearance was calculated for a target leakage upper limit specified by industry engine designers. Based on the predicted benefits of tighter HPT blade tip clearances and the proposed location of the ACC system in the engine, designers deemed secondary leakage on the order of $\sim 0.1 \%$ core flow (W25) an acceptable limit per seal location. Idealizing the ACC system as an elastic structure that could easily move inward and outward, two seals are needed for integrating the 
ACC concept into an engine, one on both the forward and aft sides of the seal carriers, placed between the seal carriers and their mating static structures. Based on these assumptions and the industry supplied flow reference level, the maximum allowable effective clearance for the ACC system is $0.0010 \mathrm{in}$.

Figure 13 compares effective clearances calculated from the experimental ACC leakage data presented in Fig. 7(a) (improved room temperature, $500^{\circ} \mathrm{F}, 800^{\circ} \mathrm{F}$, and $1000^{\circ} \mathrm{F}$ at $120 \mathrm{psig}$ ) and the industry reference level. All four experimental leakage values had lower effective clearances than the industry specified level. The room temperature leakage data had a calculated clearance of $0.0005 \mathrm{in}$. (50\% of the industry reference level). As test temperature was increased, corresponding effective clearance decreased. By $1000^{\circ} \mathrm{F}$, the calculated equivalent clearance was reduced to 0.0003 in. (30\% of the reference value).

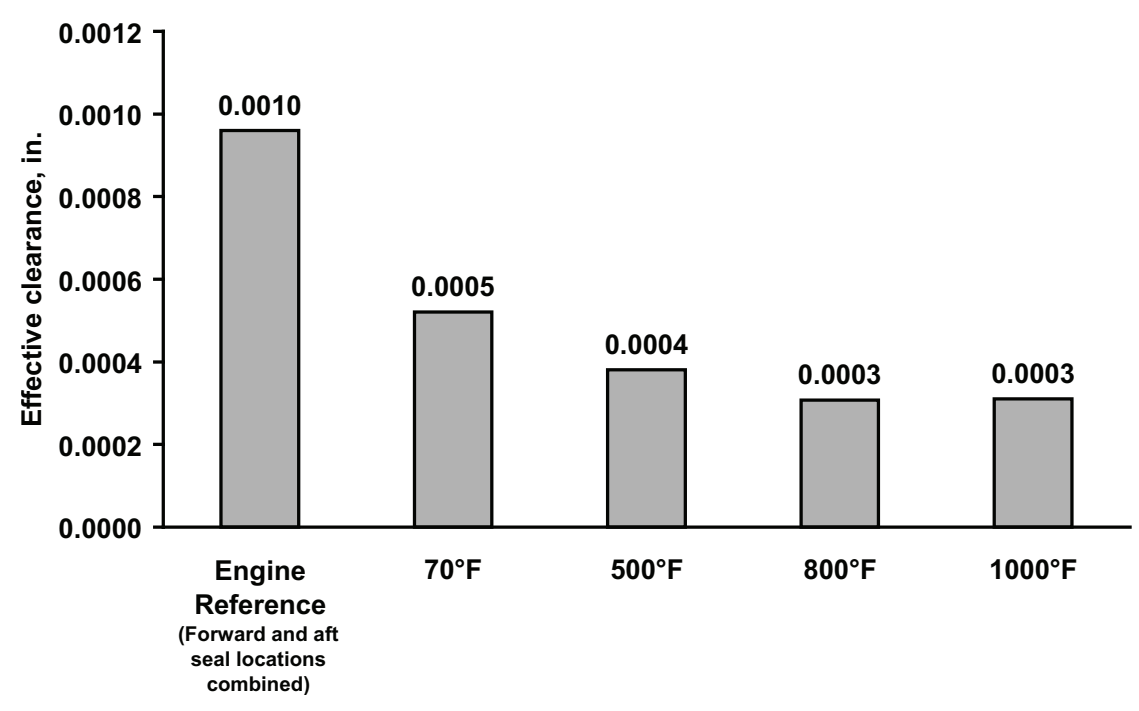

Figure 13. Calculated effective clearances for the ACC rig at 120 psig are lower than the industry engine reference level at all temperatures evaluated.

\section{Summary and Conclusions}

An active clearance control system concept and associated high temperature test rig have been fabricated and installed. The system is being used to evaluate different kinematic, actuator, controller, and clearance sensor approaches to achieve a fast-acting, mechanical active clearance control system to allow tighter tip clearances in future turbine engines. Building on room temperature evaluations from previous studies, this investigation was conducted to characterize the performance of the ACC concept test rig at elevated test temperatures. Secondary seal leakage data was collected for temperatures of $500^{\circ} \mathrm{F}, 800^{\circ} \mathrm{F}$ and $1000^{\circ} \mathrm{F}$ at chamber pressures ranging from 60 psig to 120 psig. From this data, the following observations were made:

1. Static seal leakage of the ACC system at elevated test temperatures was always lower than leakage observed at room temperature. Mass flow rates continuously decreased as test temperature was increased. At $1000^{\circ} \mathrm{F}$ and 120 psig chamber pressure, total system leakage was $0.038 \mathrm{lb}_{m} / \mathrm{s}$, a $64 \%$ decrease from the room temperature mass flow rate of $0.106 \mathrm{lb}_{m} / \mathrm{s}$ for the same seal carrier position. Much of the leakage dependence on temperature in the 800 to $1000^{\circ} \mathrm{F}$ regime can be explained via normal gas density variation with temperature. At lower test temperatures, however, other effects such as temperature dependent clearances may also play a role.

2. Static seal leakage at 500,800 , and $1000^{\circ} \mathrm{F}$ increased linearly as chamber pressure was incremented from 60 psig to 120 psig. The maximum leakage recorded during this test set was $0.057 \mathrm{lb}_{m} / \mathrm{s}\left(500^{\circ} \mathrm{F}\right.$, $120 \mathrm{psig})$, and the minimum was $0.021 \mathrm{lb}_{\mathrm{m}} / \mathrm{s}\left(1000^{\circ} \mathrm{F}, 60 \mathrm{psig}\right)$.

3. At $500^{\circ} \mathrm{F}$ and $800^{\circ} \mathrm{F}$, seal carrier position and direction of motion had a weak influence on secondary seal static leakage. Leakage values were slightly lower when the seal carriers were positioned radially 
outward and higher when they were positioned radially inward. For select seal carrier positions at the same temperatures, seal leakage during an inward stroke of the seal carriers was moderately lower than corresponding values collected during an outward stroke. At $1000^{\circ} \mathrm{F}$, there were no discernable trends to suggest any relationship between seal carrier position or direction of motion and secondary seal leakage.

4. A comparison of effective clearances for the ACC test rig (back-calculated from experimental 120 psig leakage data) to an engine industry reference level showed that the ACC rig was significantly better at all temperatures evaluated. The greatest margin of improvement occurred at $1000^{\circ} \mathrm{F}$ where the experimental effective clearance was $30 \%$ of the industry reference level.

\section{References}

\footnotetext{
${ }^{1}$ Lattime, S.B., Steinetz, B.M., Robbie, M., "Test Rig for Evaluating Active Turbine Blade Tip Clearance Control Concepts," NASA/TM-2003-212533, also AIAA-2003-4700, presented at the AIAA/ASME/SAE/ASEE conference, July, 2003, Huntsville, AL. Journal of Propulsion and Power, vol. 21 no.3, May-June 2005.

${ }^{2}$ Steinetz, B.M., Lattime, S.B., Taylor, S., DeCastro, J.A., Oswald, J., Melcher, K.A., "Preliminary Evaluation of an Active Clearance Control System Concept," NASA/TM-2005-213856, also AIAA-2005-3989. Presented at the 2005 AIAA/ASME/SAE/ASEE Joint Propulsion Conference, Tucson, AZ.

${ }^{3}$ Steinetz, B.M., Taylor, S., Oswald, J., and DeCastro, J.A., "Seal Investigations of an Active Clearance Control System Concept," NASA/TM-2006-214114, also 120-ISROMAC-11. Presented at the $11^{\text {th }}$ International Symposium of Rotating Machinery, Honolulu, HI.

${ }^{4}$ Halila, E.E., Lenahan, D.T., Thomas, T.T., "Energy Efficient Engine, High Pressure Turbine Test Hardware Detailed Design Report," NASA CR-167955, 1982.

${ }^{5}$ Lattime, S.B., Steinetz, B.M., "Turbine Engine Clearance Control Systems: Current Practices and Future Directions," Journal of Propulsion and Power, vol. 20, no. 2, NASA/TM-2002-211794, also AIAA-2002-3790. Presented at the AIAA/ASME/SAE/ASEE conference, July, 2002, Indianapolis, IN.

${ }^{6}$ General Electric Aircraft Engines, "HPT Clearance Control (Intelligent Engine Systems)-Phase I-Final Report" NASA Contract NAS3-01135, April 2004.

${ }^{7}$ Wiseman, M.W., Guo, T., "An Investigation of Life Extending Control Techniques for Gas Turbine Engines," Proceedings of the American Control Conference, IEEE Service Center, Piscataway, NJ, IEEE Catalog No. 01CH37148, vol. 5, pp. 3706-3707, 2001.

${ }^{8}$ Shapiro, Ascher H., The Dynamics and Thermodynamics of Compressible Flow, The Ronald Press Co., New York, 1953.
} 


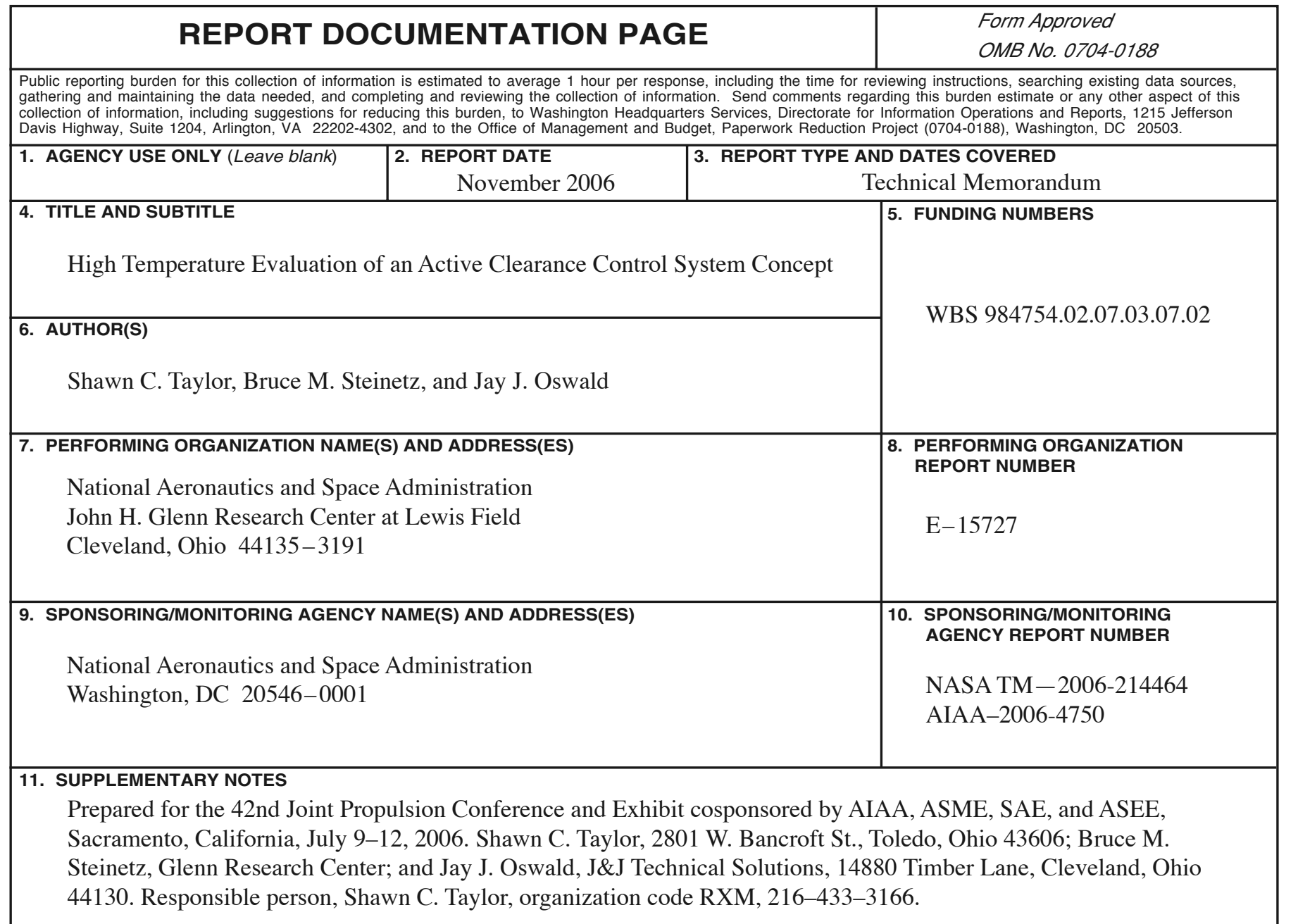

12a. DISTRIBUTION/AVAILABILITY STATEMENT

12b. DISTRIBUTION CODE

Unclassified - Unlimited

Subject Category: 37

Available electronically at http://gltrs.grc.nasa.gov

This publication is available from the NASA Center for AeroSpace Information, 301-621-0390.

13. ABSTRACT (Maximum 200 words)

A mechanically actuated blade tip clearance control concept was evaluated in a nonrotating test rig to quantify secondary seal leakage at elevated temperatures. These tests were conducted to further investigate the feasibility of actively controlling the clearance between the rotor blade tips and the surrounding shroud seal in the high pressure turbine (HPT) section of a turbine engine. The test environment simulates the state of the back side of the HPT shroud seal with pressure differentials as high as 120 psig and temperatures up to $1000{ }^{\circ} \mathrm{F}$. As expected, static secondary seal leakage decreased with increasing temperature. At $1000^{\circ} \mathrm{F}$, the test rig's calculated effective clearance (at 120 psig test pressure) was 0.0003 in., well within the industry specified effective clearance goal.

\begin{tabular}{|c|c|c|c|}
\hline \multicolumn{3}{|l|}{ 14. SUBJECT TERMS } & $\begin{array}{c}\text { 15. NUMBER OF PAGES } \\
20\end{array}$ \\
\hline
\end{tabular}



